\title{
A study on regional comprehensive performance evaluation indicator system of rational use of drugs
}

\author{
Tongda Sun ${ }^{1, a}$, Wenjie Zhou ${ }^{2}$, Yu Zhu ${ }^{3}$, Jinguo Wu ${ }^{4}$ and Luning Fan ${ }^{1}$ \\ ${ }^{1}$ Department of Health Information Management, School of Health Service and Health Management, Ningbo College \\ of Health Sciences, Ningbo City, Zhejiang Province, 315100, China \\ ${ }^{2}$ Department of Foreign Languages, School of Humanity and Social Science, Ningbo College of Health Sciences, \\ Ningbo City, Zhejiang Province, 315100, China \\ ${ }^{3}$ Health and Family Planning Bureau of Yinzhou District, Ningbo City, Zhejiang Province, 315100, China \\ ${ }^{4}$ Jintang Software Company Limited, Ningbo City, Zhejiang Province, 315041, China
}

\begin{abstract}
The current research presents the design of a 4-degree-3-level performance evaluation indicator system of rational use of drugs for health care institutions accord with the Balanced Score Card (BSC) method. Financial index, patient index, professional process index, and development and blazing new trials index are adopted in the light of scientific, guiding, operable and generalizable principles. The index weight is based on the analytic hierarchy process, and comprehensive performance evaluation indicators are calculated by a linear integrated weighting method. Its practical application in 21 state-run health care institutions in Ningbo, from 2008 to 2012, has arrived at the finding that the comprehensive performance evaluation indicator system offers a scientific, practical and effective performance management quantification and is thus worth popularizing.
\end{abstract}

\section{Introduction}

How to promote the level of medical staffs' rational use of drugs is the key link in the application of essential medicine system. Most of the previous researchers at home and abroad focus more on rational use of drugs or performance and quality evaluation on a certain level [1-4], while it is obviously insufficient in the respect of representation and completion with the abolishment of drugdependent medical policies. In order to standardize the supervision mechanism of rational use of drugs for health care institutions, it is meaningful to research so as to construct an integrative performance evaluation indicator model which can generalize and reflect the numerous elements and influential factors of rational use of drugs under the background of new medical reform. The current research presents the design of a regional comprehensive performance evaluation indicator system of rational use of drugs accord with the Balanced Score Card (BSC) method.

\footnotetext{
${ }^{a}$ Corresponding author: suntongda@foxmail.com
}

This study was supported by a grant from the Science and Technology Planning Project of Social Development in the year of 2013 of Ningbo city, Zhejiang province, China (Project number: 2013C50028). 


\section{Subjects and methords}

\subsection{Subjects}

21 state-run health care institutions in a certain city, China, have been chosen as subjects. Institutions' original data from 2008 to 2012 has been collected with a method of field investigation and used to calculate the actual value of evaluation indicators after proper statistical treatments. The average value of the actual data from 2008 to 2012 has been calculated to be the evaluation indicator for each health care institution.

\subsection{Choice of evaluation indicators}

Based on the Balanced Score Card (BSC) method, financial index, patient index, professional process index, and development and blazing new trials index have been adopted to the performance evaluation indicator system of rational use of drugs in the light of people-oriented, sustainable, policy-type, guiding, safe, operable and generalizable principles.

\subsection{Calculation and standardization of evaluation indicators}

(1) Calculate the index value of valuation indicator.

(2) Identify the properties of the indicators: the indicators were divided into three types: Positive Index (the higher was the better), Negative Index (the lower was the better), Neutral Index ( target the value around or on a moderate level).

(3) Calculate the standardized value: relatively process the indicator values according to the linear interpolation method [5] so as to get the standardized value.

\subsection{Define the indicator weight}

The Analytic Hierarchy Process (AHP) [6] was adopted to define the weight of the screening indicators on each level.

\subsection{Build a mathematical model of performance evaluation indicator system of rational use of drugs}

The linear comprehensive weighted index method [6] was adopted to build a mathematical model of performance evaluation indicator system of rational use of drugs. The computation formulas are as follows:

$$
\begin{gathered}
A_{i}=\sum_{j=1}^{m}\left(W_{j} \times Z_{i j}\right)_{(\mathrm{j}=1,2, \ldots, \mathrm{m})} \\
Z\left(A_{i}\right)=\sum_{i=1}^{n} A_{i}(\mathrm{i}=1,2, \ldots, \mathrm{n}) \\
U\left(A_{i}\right)=\frac{Z\left(A_{i}\right)}{E\left(A_{i}\right)} \times 100 \%
\end{gathered}
$$

In the above formula, $Z\left(A_{i}\right)$ stands for the comprehensive index value of the performance evaluation indicator system of rational use of drugs for each health care institution. $E\left(A_{i}\right)$ stands for 
the benchmark index of the performance evaluation indicator system for each health care institution. $U(A i)$ stands for the realization degree of the comprehensive index value of the performance evaluation indicator system for each health care institution. $A_{i}$ refers to the comprehensive evaluation indicator value of different levels. $i$ refers to the number of health care institutions to be evaluated. $j$ refers to the indicators of performance evaluation on each level. $Z_{i j}$ equals the target value (standardized value) from Ai to $Z_{j} . W_{j}$ is the weight value of $Z_{j}$ on different levels, thus, $\sum_{j=1}^{m} W_{j}=1$.

The regional comprehensive performance evaluation on rational use of drugs in a certain department or health care institution can thus be made as well as ranked according to the value of $Z$. A higher $Z$ means a better performance management on rational use of drugs.

\subsection{Data processing}

The research is statistically processed with the software SPSS 16.0 for Windows.

\section{Results}

\subsection{Evaluation indicator system}

The research group has put forward 103 preselected group indexes, after being screened, 36 of which have been ascertained as indexes on the infrastructure layer. Financial index, patient index, professional process index, and development and blazing new trials index have been adopted as the four dimensions, meanwhile, 4 first level index, 12 second level index and 36 third level index have been adopted as the three levels of the performance evaluation indicator system of rational use of drugs in health care institutions (Table 1). There are 8 financial indexes, 12 patient indexes, 11 professional process indexes, and 5 development and blazing new trials indexes respectively. 17 positive indexes, 4 neutral indexes and 15 negative indexes have been set up according to the index attribute as well.

\subsection{Results of index weighting calculation (Table 1).}

Table 1. Comprehensive performance evaluation indicator system of rational use of drugs and its weight based on BSC

\begin{tabular}{|c|c|c|c|c|c|c|}
\hline No. & $\begin{array}{l}\text { First Level } \\
\text { Index } \\
\text { (weight, \%) }\end{array}$ & $\begin{array}{l}\text { Second Level } \\
\text { Index } \\
\text { (weight, \%) }\end{array}$ & Third Level Index (weight, \%) & Unit & $\begin{array}{l}\text { Index } \\
\text { Attribute }\end{array}$ & $\begin{array}{l}\text { Synthetic } \\
\text { Weight }\end{array}$ \\
\hline 1 & \multirow[t]{5}{*}{$\begin{array}{l}\text { Financial } \\
\text { module }(20)\end{array}$} & \multirow[t]{2}{*}{$\begin{array}{l}\text { 1.Earning } \\
\text { power(35) }\end{array}$} & $\begin{array}{l}\text { Ratio of regular fiscal aid revenue to } \\
\text { operating revenue }(60)\end{array}$ & $\%$ & positive & 0.0420 \\
\hline 2 & & & $\begin{array}{l}\text { Operating income and expenditure } \\
\text { balance ratios }(40)\end{array}$ & $\%$ & neutral & 0.0280 \\
\hline 3 & & \multirow[t]{3}{*}{$\begin{array}{l}\text { 2.Spending } \\
\text { power(35) }\end{array}$} & $\begin{array}{l}\text { Outpatient's average medicine cost per } \\
\text { doctor visit ( } 25)\end{array}$ & RMB & negative & 0.0175 \\
\hline 4 & & & $\begin{array}{l}\text { Average daily medicine cost of } \\
\text { hospitalization (20) }\end{array}$ & RMB & negative & 0.0140 \\
\hline 5 & & & $\begin{array}{l}\text { Average medicine cost of each } \\
\text { discharged patient (25) }\end{array}$ & RBM & negative & 0.0175 \\
\hline
\end{tabular}




\section{ICMSB2016}

\begin{tabular}{|c|c|c|c|c|c|c|}
\hline 6 & & & $\begin{array}{l}\text { Average ratio of pharmaceutical affairs } \\
\text { cost price to each hundred-yuan drug } \\
\text { sales revenue (30) }\end{array}$ & RMB & negative & 0.0210 \\
\hline 7 & & $\begin{array}{l}\text { 3.Support } \\
\text { capability(30) }\end{array}$ & $\begin{array}{l}\text { Coverage of health care institutions' } \\
\text { management system of rational use of } \\
\text { drugs }(60)\end{array}$ & $\%$ & positive & 0.0360 \\
\hline 8 & & & Rate of qualified prescriptions (40) & $\%$ & positive & 0.0240 \\
\hline 9 & \multirow[t]{12}{*}{$\begin{array}{l}\text { Patient } \\
\text { module (35) }\end{array}$} & \multirow[t]{5}{*}{$\begin{array}{l}\text { 1.Medicine } \\
\text { attributes (35) }\end{array}$} & $\begin{array}{l}\text { Average medicine variety on each } \\
\text { prescription (25) }\end{array}$ & type & neutral & 0.0306 \\
\hline 10 & & & $\begin{array}{l}\text { Average variety of essential drugs in } \\
\text { each prescription (25) }\end{array}$ & type & Positive & 0.0306 \\
\hline 11 & & & $\begin{array}{l}\text { Average variety of antibiotics in each } \\
\text { prescription (25) }\end{array}$ & type & negative & 0.0306 \\
\hline 12 & & & $\begin{array}{l}\text { Percentage of antibiotic prophylaxis } \\
\text { applied on operated patients (15) }\end{array}$ & $\%$ & negative & 0.0184 \\
\hline 13 & & & $\begin{array}{l}\text { Percentage of antibiotics applied on } \\
\text { inpatients (10) }\end{array}$ & $\%$ & negative & 0.0123 \\
\hline 14 & & \multirow[t]{3}{*}{$\begin{array}{l}\text { 2.Image and } \\
\text { prestige (25) }\end{array}$} & $\begin{array}{l}\text { Patients' awareness rate of rational use } \\
\text { of medicine (35) }\end{array}$ & $\%$ & Positive & 0.0306 \\
\hline 15 & & & $\begin{array}{l}\text { Utilization of generic names of drugs } \\
\text { (25) }\end{array}$ & $\%$ & Positive & 0.0219 \\
\hline 16 & & & $\begin{array}{l}\text { Utilization of essential drugs or } \\
\text { formularies (40) }\end{array}$ & $\%$ & Positive & 0.0350 \\
\hline 17 & & \multirow{4}{*}{$\begin{array}{l}\text { 3.Patients' } \\
\text { needs }\end{array}$} & Average cost of each prescription (35) & RMB & negative & 0.0490 \\
\hline 18 & & & $\begin{array}{l}\text { Percentage of essential drugs in each } \\
\text { prescription (25) }\end{array}$ & $\%$ & positive & 0.0350 \\
\hline 19 & & & $\begin{array}{l}\text { Cost of antibiotics in each prescription } \\
\text { (30) }\end{array}$ & $\%$ & negative & 0.0420 \\
\hline 20 & & & $\begin{array}{l}\text { Average expenses on antibiotics from } \\
\text { patients who have accepted antibiotic } \\
\text { treatment }(10)\end{array}$ & RMB & negative & 0.0140 \\
\hline 21 & \multirow{6}{*}{$\begin{array}{l}\text { Project } \\
\text { process } \\
\text { module (35) }\end{array}$} & \multirow{5}{*}{$\begin{array}{l}\text { 1.Quality of } \\
\text { medicine use } \\
\text { (45) }\end{array}$} & Utilization of antibiotics (20) & $\%$ & negative & 0.0315 \\
\hline 22 & & & Utilization of injections (15) & $\%$ & negative & 0.0236 \\
\hline 23 & & & Utilization of steroids (10) & $\%$ & negative & 0.0158 \\
\hline 24 & & & $\begin{array}{l}\text { Proportion of prescriptions with over } \\
\text { two kinds of antibiotics ( } 30 \text { ) }\end{array}$ & $\%$ & Negative & 0.0473 \\
\hline 25 & & & $\begin{array}{l}\text { Reports rate on adverse drug reactions } \\
\text { (25) }\end{array}$ & $\%$ & Positive & 0.0394 \\
\hline 26 & & 2.Efficiency & Average consultation time (40) & Min. & Positive & 0.0420 \\
\hline
\end{tabular}




\begin{tabular}{|c|c|c|c|c|c|c|}
\hline 27 & & \multirow{2}{*}{$\begin{array}{l}\text { of medicine } \\
\text { use (30) }\end{array}$} & Average time of compounding (40) & Sec. & Positive & 0.0420 \\
\hline 28 & & & $\begin{array}{l}\text { Average days of antibiotic prophylaxis } \\
\text { for operating patients }\end{array}$ & Day & Negative & 0.0210 \\
\hline 29 & & \multirow{3}{*}{$\begin{array}{l}\text { 3.Medicine } \\
\text { follow-up } \\
(25)\end{array}$} & $\begin{array}{l}\text { Percentage of medicine labeling } \\
\text { integrity (30) }\end{array}$ & $\%$ & Positive & 0.0263 \\
\hline 30 & & & $\begin{array}{l}\text { Percentage of antibiotic treated patients } \\
\text { being sent to pathogenic examinations } \\
\text { and drug sensitive tests (10) }\end{array}$ & $\%$ & Positive & 0.0088 \\
\hline 31 & & & $\begin{array}{l}\text { Patients' degree of satisfaction in } \\
\text { rational use of drugs }(60)\end{array}$ & $\%$ & Positive & 0.0525 \\
\hline 32 & \multirow{5}{*}{$\begin{array}{l}\text { development } \\
\text { and creative } \\
\text { module (10) }\end{array}$} & \multirow{2}{*}{$\begin{array}{l}\text { 1.Diathesis } \\
\text { and } \\
\text { capabilities } \\
(40)\end{array}$} & $\begin{array}{l}\text { Percentage of health technicians with } \\
\text { middle and senior titles }(60)\end{array}$ & $\%$ & Neutral & 0.0240 \\
\hline 33 & & & $\begin{array}{l}\text { Thesis published by health technicians } \\
\text { per capita ( } 40)\end{array}$ & article & Positive & 0.0160 \\
\hline 34 & & $\begin{array}{l}\text { 2.Information } \\
\text { capacity (35) }\end{array}$ & $\begin{array}{l}\text { Information process degree of rational } \\
\text { use of drugs (100) }\end{array}$ & $\%$ & Positive & 0.0350 \\
\hline 35 & & \multirow[t]{2}{*}{$\begin{array}{l}\text { 3.Ability to } \\
\text { inspire }(25)\end{array}$} & $\begin{array}{l}\text { Coverage of on-the-job vocational } \\
\text { training on rational use of drugs }(70)\end{array}$ & $\%$ & Positive & 0.0175 \\
\hline 36 & & & $\begin{array}{l}\text { Annual earnings per capita of the staff } \\
\text { members on the payroll }(30)\end{array}$ & RMB & neutral & 0.0075 \\
\hline
\end{tabular}

\subsection{Actual application of the comprehensive performance indicator system of rational use of drugs in health care institutions from 2008 to 2012 in a Chinese city}

The average composite performance index of rational use of drugs among 21 health care institutions from 2008 to 2012 in a Chinese city was 61.15 . The average index of the U Institution was the highest 72.11 in 2012, while in the year 2009, that of the K Institution was merely 44.26 as the lowest. Judging from the average index from 2008 to 2012, the T Institution, scoring 66.84, achieved the highest composite performance index of rational use of drugs, while the B Institution only accounted for 50.23. The top three were the $\mathrm{T}$ Institution, the Q Institution and the $\mathrm{E}$ Institution in proper sequence with scores $66.84,66.48$ and 65.38 respectively. The last three were the B Institution, the $\mathrm{K}$ Institution and L Institution with scores 50.23, 52.15 and 55.93 in file (Table 2).

Table 2. Results of the performance evaluation of rational use of drugs in health care institutions from 2008 to 2012 in a Chinese city

\begin{tabular}{|c|c|c|c|c|c|c|c|c|c|c|}
\hline \multirow[b]{2}{*}{ INSTs } & \multicolumn{2}{|c|}{$\begin{array}{c}\text { Financial module } \\
\text { indicator }\end{array}$} & \multicolumn{2}{|c|}{$\begin{array}{l}\text { Patient module } \\
\text { indicator }\end{array}$} & \multicolumn{2}{|c|}{$\begin{array}{l}\text { Project process } \\
\text { module indicator }\end{array}$} & \multicolumn{2}{|c|}{$\begin{array}{l}\text { Develop and creative } \\
\text { module indicator }\end{array}$} & \multicolumn{2}{|c|}{$\begin{array}{c}\text { Comprehensive } \\
\text { performance evaluation }\end{array}$} \\
\hline & $\begin{array}{c}\text { Performance } \\
\text { index }\end{array}$ & ranks & $\begin{array}{l}\text { Performan } \\
\text { ce index }\end{array}$ & ranks & $\begin{array}{l}\text { Performan } \\
\text { ce index }\end{array}$ & ranks & $\begin{array}{l}\text { Performance } \\
\text { index }\end{array}$ & ranks & $\begin{array}{c}\text { Total } \\
\text { Performance } \\
\text { index }\end{array}$ & ranks \\
\hline $\mathrm{A}$ & 11.73 & 17 & 16.92 & 19 & 21.70 & 6 & 6.75 & 9 & 63.49 & 6 \\
\hline B & 9.24 & 21 & 14.81 & 21 & 21.17 & 7 & 9.32 & 1 & 63.29 & 7 \\
\hline $\mathrm{C}$ & 11.96 & 16 & 16.89 & 20 & 22.47 & 4 & 7.05 & 8 & 65.19 & 4 \\
\hline $\mathrm{D}$ & 11.57 & 18 & 19.09 & 18 & 23.31 & 2 & 6.70 & 10 & 66.48 & 2 \\
\hline$E$ & 14.14 & 4 & 24.79 & 1 & 18.76 & 17 & 8.02 & 4 & 58.37 & 17 \\
\hline $\mathrm{F}$ & 12.77 & 10 & 24.43 & 5 & 19.10 & 15 & 4.04 & 19 & 59.53 & 15 \\
\hline $\mathrm{G}$ & 13.39 & 9 & 23.51 & 7 & 18.59 & 18 & 2.62 & 21 & 56.36 & 18 \\
\hline $\mathrm{H}$ & 13.39 & 8 & 20.66 & 15 & 17.40 & 20 & 4.10 & 18 & 52.15 & 20 \\
\hline $\mathrm{I}$ & 14.20 & 2 & 23.26 & 10 & 18.07 & 19 & 4.49 & 16 & 55.93 & 19 \\
\hline $\mathrm{J}$ & 12.22 & 15 & 23.34 & 9 & 19.94 & 11 & 5.82 & 13 & 60.83 & 11 \\
\hline
\end{tabular}




\begin{tabular}{|c|c|c|c|c|c|c|c|c|c|c|}
\hline $\mathrm{K}$ & 12.43 & 13 & 22.22 & 13 & 13.40 & 21 & 5.01 & 14 & 50.23 & 21 \\
\hline $\mathrm{L}$ & 11.11 & 19 & 20.64 & 16 & 19.68 & 12 & 7.11 & 7 & 60.72 & 12 \\
\hline $\mathrm{M}$ & 14.17 & 3 & 23.03 & 11 & 20.94 & 9 & 3.33 & 20 & 62.29 & 9 \\
\hline $\mathrm{N}$ & 12.51 & 12 & 22.42 & 12 & 22.72 & 3 & 7.69 & 5 & 65.38 & 3 \\
\hline $\mathrm{O}$ & 12.57 & 11 & 19.94 & 17 & 21.10 & 8 & 6.59 & 11 & 62.88 & 8 \\
\hline $\mathrm{P}$ & 14.07 & 5 & 24.77 & 3 & 20.11 & 10 & 4.37 & 17 & 62.02 & 10 \\
\hline $\mathrm{Q}$ & 13.85 & 7 & 23.92 & 6 & 22.01 & 5 & 8.27 & 3 & 63.80 & 5 \\
\hline $\mathrm{R}$ & 14.25 & 1 & 23.45 & 8 & 19.05 & 16 & 7.33 & 6 & 58.65 & 16 \\
\hline $\mathrm{S}$ & 13.88 & 6 & 21.99 & 14 & 19.14 & 14 & 8.38 & 2 & 59.84 & 14 \\
\hline $\mathrm{T}$ & 12.39 & 14 & 24.78 & 2 & 23.48 & 1 & 6.20 & 12 & 66.84 & 1 \\
\hline $\mathrm{U}$ & 9.96 & 20 & 24.54 & 4 & 19.23 & 13 & 4.85 & 15 & 60.36 & 13 \\
\hline
\end{tabular}

\section{Discussion}

In China, National Essential Drug System (NEDS) is an important and difficult part of the new health care reform. To set up and manage an effective NEDS, a scientific and effective performance evaluation system of rational use of drugs is much needed. The research integrates experts' suggestions with the current practice of rational use of drugs in health care institutions, so as to set up a representative, guiding, practical, independent and sensitive indicator system. What's more, its practical application in 21 state-run health care institutions from 2008 to 2012 in a Chinese city, has arrived at findings accord with the operational state, which has further revealed the correctness, effects, reliability and scientific nature of the evaluation findings. Thus, being repeatable and feasible, the performance indicator system has been proven a practical and effective performance management quantization tool which is worth of populating.

However, under the background of new national health care reform, it is a huge systematic project to set up a performance evaluation system of rational use of drugs for health care institutions. The various levels of health care institutions and their unique developmental characteristics have directly led to the complexity and difficulty in setting up a performance evaluation system of rational use of drugs. Despite the fact that the current research have managed to choose fewer but better indicators in an objective and overall way, we believe there are significant improvements still to be made. Abundant, repeated investigations and applications wait to be planned and then carried out step by step. Aimed at an ambition of digitalization of performance evaluation indicator system of rational use of drugs, the construction of residents' electronic health files (HER) should be progressively refined, so as to make the evaluation system a valid method in measuring the management effects of health care institutions' performance evaluation of rational use of drugs.

\section{References}

1. K. Holloway, L. v. Dijk. Rational use of drugs, Geneva, WHO/EMP/MIE, The world medicines situation (2011).

http://www.who.int/medicines/areas/policy/world_medicines_situation/WMS_ch14_wRational.pd f.

2. National Monitoring Office for rational use of drugs. The profile of rational use of drugs in foreign countries, China Licensed Pharmacist, 8, 14-16 (2011).

3. Ministry of Health of P.R.China, Progress in essential drug system in China (2011).

http://www.moh.gov.cn/publicfiles/business/htmlfiles/mohywzc/s7652/201110/53137.htm

4. T. D. Sun, Zh. Q. Gu, L.Wang. etc. A study on the impact of essential medicines system on medical staff's behaviour, Chinese Hospitals, 16, 23-25 (2012).

5. L. M. Zhang, L. J. Huang, J. L. Xia. etc. Study on target standardization of comprehensive evaluation, Chinese Journal of Health Statistics, 11, 1-4 (1994).

6. Y. R. Ren, Q. O. Liu, (eds.), Fundamental technology of health management --- pragmatic operational research and systems engineering, Joint publishing house of BMUC\&PUMC, 177190(1993). 